\title{
Interdisciplinarity in French Social Sciences Scientific Journals*
}

\author{
Eric Brun
}

Centre Européen de Sociologie et de Science Politique (CESSP-CSE)

I n Europe, interdisciplinarity has imposed itself as a watchword for scientific policies. The program which combines European research and innovation funding for the years 2014-2020, "Horizon 2020", aims at supporting "genuinely interdisciplinary projects, likely to respond to the major Economics and Social Challenges". These policies connect interdisciplinarity to a project funding approach included in a lineage of performative analysis by the authors of Re-Thinking Science and The New Production of Knowledge (Gibbons et al., 1991; Nowotny et al., 2001; Shinn, 2002; Lamy, 2007).

The purpose of this paper is not to make a stand on the debates which reinvigorate such calls for the interdisciplinarity, and which traditionally oppose those who associate the scientific approach with the monodisciplinair oriented specialization with those who see in this specialization a confinement and in fine an obstacle to the knowledge of increasingly complex facts; which also and maybe above all collide with the differing views about the pertinent forms of combinations among disciplines, among which the profusion of used labels by each other (multidisciplinary, interdisciplinary, transdisciplinary, auxiliary

* A tradução do original, em francês, "L'Interdisciplinarité à l'Aune des Revues Scientifiques: Note de Recherche sur les Revues Françaises en Sciences Sociales" é de Maria Lúcia Borba.

DADOS - Revista de Ciências Sociais, Rio de Janeiro, vol. 60, n3, 2017, pp. 867 a 894. 
sciences, neighboring sciences) testify, in part, and which we could out of doubt demonstrate that they sustain as their fundamental traces of... disciplinarity. Here, our purpose is to contribute to a better knowledge on the social logic governing encounters and collaborations among researchers working in the various disciplinary fields, traditionally separated within the Social and Human Sciences (SHS).

While observing research activities, we are led also to recognize that bridges and combinations more or less frequent between the different "disciplines" within the Social Sciences already exist. The disciplines do not function as closed boxes: they open various corridors and they are themselves submitted to the struggle for the delimitation of their borders, borders which could be more or less porous from case to case. In other words, the circulations and collaborations exist but they are also unequally probable. This also means that they will not be seen as a mere coincidence of the encounter of researchers or of pure personal choice. What is more, they will not be seen as sufficient to predict the disappearance of the disciplinary specialization (Heilbron, Gingras, 2015).

Concerning SHS research in France, different sources permit to map connections among disciplines since they are defined by the institutional breakdowns of their own research national grounds. This is, for example, the annual statistical reports established after the year 2005 by the Ministère de l'Enseignement supérieur et de la Recherche en France on those who are qualified to take up the functions of "Maittre de conferences" and of "Professeurs des universtités"1.

In France, access to an academic career is mainly linked to the recruitment as a teacher-researcher in the higher education establishments such as universities (one starts his or hers career as a "Maître de conferences", before eventually becoming "Professeurs des universités"). Other means of accessing exist, such as the recruitment within research organizations like the Centre National de la Recherche Scientifique (CNRS), for positions as "chargés" or "directeurs de recherche" or also the recruitment by the École des Hautes Études en Sciences Sociales (EHESS), but these are numerically less. In order to apply for positions of Maitres de conférences open to universities, the candidate must have submitted a thesis and obtained a PhD diploma, and must also have been "qualified" for this function by a national instance, the Conseil National des Universités (CNU), which is 
divided into various sections comprising the "disciplines" or the clusters of various neighboring "disciplines".

The annual data which shows which of CNU's disciplinary sections qualify the doctors who have obtained their qualification at the same time in various sections, allow, on the one hand, to discriminate the disciplines according to their degree of "openness" and, on the other hand, to access the institutional proximities between the disciplines at the university, according to the occurrence in which they are associated within the "co-qualified" 2 .

The research disciplinary structures can be observed not only at the level of the assignment to the different disciplines by the candidates to recruitment at the universities, but also at the level of the research "products". As a matter of fact, the journals offer an interesting observation site of the interdisciplinary circulation and the multidisciplinary collaboration. It is possible, for example, to observe the quotes made by the main journals for each discipline. However, this approach implies the limitation of the studied journals main core to a reduced number of general (generalist) journals considered as "major" and to agree beforehand with the discipline attached to these journals ${ }^{3}$. This classification of journals in scientific disciplines itself deserves to be seen as an indication of the authorized combinations or, on the contrary, the rarely crossed disciplinary boundaries among the disciplines or the disciplinary domain(s).

Therefore, this article will engage in what may seem, at a first site, a methodological difficulty - the difficulty to order the journals themselves according to their pertaining discipline. We will give attention to put into practice the assignment to Social Sciences journals of one or more disciplines attached to them. If these practices of classification, implemented by the organizations responsible for the numerical access to the scientific resources, by the agencies evaluating research activities, or even by the journals themselves when they define their field of reference, do not mention anything about the effective collaboration among the researchers of different disciplines, we are inclined to suppose that they reflect diffuse representations of relationships among disciplines and - particularly in the case of the classifications established by the organizations in charge of the evaluation - a performative effect by the fact of delineating the space of probable combinations and therefore possible combinations. 


\section{Sources and methodologies}

This research note is supported by a database (built by us within the framework of the European project Interco-SSH) comprising 198 "French" journals classified in 2013 by the Agence d'Évaluation de la Recherche et de l'Enseignement Supérieur (AERES ${ }^{4}$ ) in the fields of Economics-Management $(n=82)$, Sociology-Demography $(n=76)$, Anthropology $(n=62)$, or Political Science $(n=54)$. After 2008, AERES established the lists of journals according to disciplines (or disciplines' ensembles in the case of, for example, Economics-Management and Sociology-Demography) in order to help research evaluation activities. Each list is the product of the disciplinary commissions, which propose regular updating ${ }^{5}$. The same journals may be classified under different lists at the same time. Therefore, this will allow to observe which disciplines or sets of disciplines are frequently or rarely associated by the journals, based on their rankings by AERES. With a view to achieving the graphical representations of connections between disciplines in the form of networks, we have added to this initial corpus French journals recognized in the fields of Philosophy $(n=22)$ and Psychology $(n=62)$.

To quickly separate the "French" journals within these lists, we used the "JournalBase" (http://journalbase.cnrs.fr/) platform, which allows a research of journals using discipline, language or nationality filters.

Nevertheless, the "nationality" filter proposed by this tool refers to the nationality of the publisher, which is an imperfect indicator of the nationality of the magazines itself. Therefore, we have added to our sample of journals, some editors not located in France but who may, however, be regarded as French, at least partially, by their editorial team or earlier editor.

\section{THE EDITORIAL POLICIES OF JOURNALS AT THE TIME OF "INTERDISCIPLINARITY"}

Currently, the French Social Sciences journals are characterized by the frequent display of a "multi", "inter" or "transdisciplinary" identity. Given the way they present their field of expertise (on their website), it becomes clear that many of the journals of our base - about 120 of $200-$ explicitly confirm such a dimension. This overview sets the scene to 
identify, at the same time, different strategies for the presentation of the journals' disciplinary identity.

In some cases, the journals simply claim an opening regarding the so-called "neighboring" or "related" disciplines toward what is considered the journals" "reference discipline". Their identity is defined by a discipline, as in the case of the journal Ethnologie Française: firstly, as the "witness of contemporary debates in Anthropology of France and French-speaking countries of Europe the last fifteen years"; secondly, it proposes to ensure a dialogue "with the neighboring disciplines, History and Sociology". This is also the case of journals such as L'Année Sociologique, which presents itself as a "reference" journal in Sociology, expressing its actual "ambition of not stopping at the disciplinary boundaries"; as Population that wishes to welcome "original work by researchers on Demography and on related disciplines" such as Sociology, Economics, Anthropology, History, Geography, or also Epidemiology; or as Réseaux which, although "primarily oriented to Sociology," explain that the journal addresses "the communication problems in a multidisciplinary way."

In other cases, the ways journals present themselves consist of being a part of the Social and Human Sciences in general without displaying any privileged discipline within them. This is the case particularly but not only - of the non-generalist journals whose identity is defined primarily by a specialized theme or a given cultural area, such as the journal Espace, Populations, Sociétés, which sees itself as "pluridisciplinary" journal and explains:

The apprehension of the significance of phenomena currently affecting populations and societies addressed by researchers from different disciplinary backgrounds provides a unique opportunity for dialogue. [...]By bringing together in one publication the same theme, with the requirements that we have just stated, the work of researchers from different branches of the sciences of man and society, "Espace, Populations, Sociétés" desires to offer a meeting platform that allows everyone to preserve the originality of their own approach to a discipline, while participating in the necessary communication between neighboring sciences without which there can be no progress of knowledge.

These journals sometimes privilege both denominations "Social Sciences" or "Society Sciences", some other times that of "Human and 
Social Sciences" - although more rarely, undoubtedly considering that disciplines like History are underrepresented in our database (they are present except when they are classified elsewhere under one of the subject areas selected by our survey) - the denominations "Sciences of Man" or "Human Sciences".

If the above examples reflect the recognition of the autonomy of the various disciplines, to claim a disciplinary openness is however sometimes exaggerated, as when the terms "inter" and "transdisciplinarity" are preferred upon those of "multi" or "multidisciplinary". The journal Communications, for example, founded in 1961 by Georges Friedmann, Roland Barthes and Edgar Morin, claims today a "demanding transdisciplinarity." Sometimes we notice redundant formulas, as in the two following presentations:

The Peer-reviewed scientific journal, Societies and youths in difficulty strive to promote $[\ldots]$ the plurality of disciplines approach and develop multidisciplinary perspectives or interdisciplinary [...].

La Revue de 1'entrepreneuriat (Journal of Entrepreneurship) [...] welcomes all disciplinary perspectives (Management, Economics, Sociology, Anthropology, Geography, History, Ethnography, ...), multidisciplinary, interdisciplinary or transdisciplinary relating to this area of research.

That means that the current trend is hardly the proud claim of exclusive ownership of a journal regarding one discipline. Certainly, one can quote the journal Sociologie, an "academic" and "general" journal, founded by the sociologist Serge Paugam in 2000, who warned: "As the title indicates, this is a journal of Sociology (and not of Social Science) [...]." It is still necessary to clarify that this journal itself added, at a continuation of its presentation, to having "open borders with other disciplines [...]." However, it may be noted that only two or three journals in our corpus claim their openness to outside areas of SHS, like for example Natures, Sciences et Sociétés which explains that its central theme, that of "interactions between societies and their environment","requires a wide variety of disciplines (Earth Sciences, Life, Nature, Human and Social Sciences, Technical Sciences ...)."

Anyway, we understand that to classify journals by discipline is a delicate operation. And, in fact, as well as the journal lists produced by the organizations responsible for the researchers' access to scientific resources generally leave the ability to assign multiple disciplines to 
Table 1

Distribution of Journals Staff According to the Number of Disciplines' Ensembles AERES

\begin{tabular}{|c|c|c|}
\hline & $94(47 \%)$ \\
\hline \multicolumn{2}{|c|}{$\begin{array}{l}\text { Journals classified by AERES under } 1 \text { discipline } \\
-2 \text { disciplines }\end{array}$} & $59(30 \%)$ \\
\hline & -3 disciplines & $22(11 \%)$ \\
\hline & -4 disciplines & $15(8 \%)$ \\
\hline & -5 disciplines & $7(4 \%)$ \\
\hline & -6 disciplines & $1(1 \%)$ \\
\hline Total sample & & $198(100 \%)$ \\
\hline
\end{tabular}

Explanation: 94 journals in the sample are classified under one discipline's ensemble by AERES (or $47 \%$ ), 59 under two combinations of disciplines, etc.

the same journal, in France the agency responsible since 2006 to assess research recognizes a multidisciplinary dimension regarding many Social Science journals. About $50 \%$ of journals in our corpus are indeed present in at least two AERES disciplinary lists.

The number of journals gradually decline as the number of disciplines covered increases, a sign that we cannot recognize that boundaries are disappearing between disciplines or disciplinary fields within Humanities and Social Sciences.

\section{THE JOURNALS INTERDISCIPLINARY EDITORIAL TEAMS}

One might think, at first glance, that the frequent demand for a "multi", "inter" or "transdisciplinary" openness reflects less the actual practices than the current distribution of a discourse opposing "openness", "dialogue" and "interconnection" to "sclerosis". It would nevertheless be wrong to regard it as not accompanied by any practical application. If the study by the authors of various articles and the citation practice reach beyond the scope of this article, we have been nevertheless interested in the composition of the journal editorial team. Many are indeed Social Science journals that, relating to the disciplinary affiliation of the members of their editorial boards, appear straddle between several disciplines - or at least open themselves to one or more related disciplines vis-à-vis the main discipline.

If one sets aside 46 journals (or approximately $23 \%$ of our sample), whose editorial team was not counted by us (these are relevant journals related to Management Sciences) or about which we do not 
have information ${ }^{6}$, only 22 journals show no disciplinary openness with respect to the editorial team (11\%), to which should be added 26 disciplinary journals whose openness is very limited in that only one or two members of the team demonstrate a different disciplinary affiliation vis-à-vis the other members (13\%). The most common case is that of the journals whose editorial board, while being dominated by representatives of one - or more rarely two - disciplines, is characterized by the presence of more than two members from one or more other disciplines. This case concerns 76 journals $(38 \%)$ in our sample. In a last case involving 30 sample journals (14\%), no major discipline outstands clearly vis-à-vis the disciplinary affiliations of the editorial team.

Among the hundred journals whose editorial team is characterized by a significant openness to disciplinary affiliations (combining the third and last scenario mentioned above), we found mainly journals specialized on a theme (like Archives de sciences sociales des religions, Droit et culture, Retraite et société, or on a certain cultural area (as the L'Année du Maghreb, Lusotopie, Les Cahiers d'extrême-Asie, Tiers-Monde, Politique. A significant number of general journals is also to be found, such as Tracés, Genèses, Actes de la recherche en sciences sociales or La Revue de synthèse; not to mention journals which reference discipline has historically constituted itself at the crossroads of several disciplines such as Population (a Demography journal which includes demographers, statisticians, economists and sociologists) and $\mathrm{La}$ Revue française de pédagogie (which examines Education Sciences and includes sociologists and psychologists).

This practice of disciplinary openness of the editorial team also seems to vary according to the main subject of the journal (established in terms of the composition of their writing team). It appears, in fact, that openness is much less widespread among the French journals which main subject is Economics, than among the French journals which main discipline is Sociology or Political Science. In this case, $33 \%$ of the 30 journals from our corpus main discipline identified ${ }^{7}$ as Economics are characterized by a clear disciplinary openness, against $55 \%$ of 29 journals identified as belonging primarily to Social and Cultural Anthropology, $61 \%$ of 33 Sociology journals and $71 \%$ of the 14 Political Science journals.

The composition of the editorial teams of Social Science journals lead us to assume that collaborations between researchers among various 
Social Sciences groups will not be seen as a marginal phenomenon. However, disciplinary connections made by the journals themselves seem unequally probable and show rather a relatively stable structure relating to affinities and distances among the different SHS disciplines.

\section{Combinations Unequally Recognized by Institutions}

In order to identify these collaborations within the organization of the journals, a first approach would be to continue to study their editorial boards. At present, this would be too time-consuming. One can, however, identify such connections by examining how they are recognized by the evaluation body, which is, in this case, AERES. Indeed, these connections say little about the real collaborations between researchers from different disciplines. Nevertheless, given the underlying issues during the establishment of these lists and given that they are supposed to serve as a tool for the operations concerning the evaluation of research activities, their study may probably enable disciplinary associations.

Firstly, we observe that these disciplinary groups are unevenly open. The journals classified in the field of Political Science are also frequently classified elsewhere under other disciplines (only $8 \%$ of them are classified only under Political Science while, on the contrary, $34 \%$ are classified under 3 disciplines at the same time) what undoubtedly reflects the fact that the constitution of this discipline in France took place itself at the crossroads of several epistemological and methodological approaches: the French Political Science is included under both Public and Constitutional Law (from which it derives), Political Sociology, Political Theory, International Relations... Also the main French Political Science journals are classified under several disciplines at the same time: La Revue française de science politique as well as Critique international are classified under Political Science, Sociology-Demography and Law, Politix under Political Science, Sociology-Demography and Law and Sciences et techniques des activités sportives (Sport Sciences and Techniques) (Staps).

Similarly, the Sociology-Demography field appears substantially more "open" than Economics-Management, Anthropology, Philosophy, and, especially, Psychology. While only 20\% of French 
journals in the Sociology-Demography list are only present in one list, this proportion rises to $42 \%$ for French journals in the Economics-Management list, to 55\% for those in the Anthropology and Philosophy lists, and to $89 \%$ for those in the Psychology list.

Table 2

Number of Disciplines under Which the Journals Are Recognized by AERES

\begin{tabular}{l|r|r|r|r|r|r|r}
\hline & \multicolumn{1}{c|}{$\mathbf{1}$} & \multicolumn{1}{c|}{$\mathbf{2}$} & \multicolumn{1}{c|}{$\mathbf{3}$} & \multicolumn{1}{c|}{$\mathbf{4}$} & \multicolumn{1}{c|}{$\mathbf{5}$} & \multicolumn{1}{c}{$\mathbf{6}$} & \multicolumn{1}{c}{ Total } \\
\hline Sociology-Demography & $15(20 \%)$ & $25(33 \%)$ & $13(17 \%)$ & $15(20 \%)$ & $7(9 \%)$ & $1(1 \%)$ & $76(100 \%)$ \\
Political science & $3(6 \%)$ & $13(24 \%)$ & $18(33 \%)$ & $13(24 \%)$ & $6(11 \%)$ & $1(2 \%)$ & $54(100 \%)$ \\
Economics-management & $42(51 \%)$ & $24(29 \%)$ & $5(6 \%)$ & $7(9 \%)$ & $4(5 \%)$ & 0 & $82(100 \%)$ \\
Anthropology & $34(55 \%)$ & $11(18 \%)$ & $6(10 \%)$ & $5(8 \%)$ & $5(8 \%)$ & $1(2 \%)$ & $62(100 \%)$ \\
Psychology & $55(89 \%)$ & $6(10 \%)$ & 0 & 0 & $1(1 \%)$ & 0 & $62(100 \%)$ \\
Philosophy & $12(55 \%)$ & $5(23 \%)$ & $4(18 \%)$ & $1(4 \%)$ & 0 & 0 & $22(100 \%)$ \\
\hline
\end{tabular}

Explanation: 15 of 76 journals classified under Sociology-Demography appear only within this disciplines' ensemble (that is $20 \%$ ), 25 of 76 journals are classified under two disciplines' ensembles (that is $33 \%$ ), etc.

What about the frequency of various disciplinary combinations? Note, first, that the most established combinations are represented by the disciplines that appear together in one list: Sociology and Demography; Economics and Management; Geography, Urban Planning; History, Art History and Archeology, etc. The division by "disciplines' ensemble" used by AERES generally reflects the institutional divisions as they have been progressively developed within universities. Sociology and Demography, for example, include a section on the Conseil national des universities (CNU), since its foundation in 1972 under the title of Conseil consultatif des universités ${ }^{8}$. And if Management has, since the late 1960s, an autonomous section within CNU, and independent from Economics within the "agrégation $d u$ supérieur" , Management is traditionally strongly linked to Economics in the university world (Economics and Management are also equipped with a section within CNRS).

As for Psychology, we must likewise refrain from interpreting the above table as a sign of "closure". It is interesting to note that the list, besides being entitled "Psychology, Ethology, Ergonomics", consists for a large part of medical journals, which were therefore not intended to be present in other SHS fields selected here. It also reflects the institutional history of Psychology in France, torn between Medicine and Natural and Human Sciences. 


\section{Sociology at the heart of the "Social Sciences"}

If some combinations are introduced by the same principle of breaking down lists in "disciplines' ensembles", others only appear when we observe which disciplinary fields are covered in more detail by the journals classified under several lists.

To highlight the uneven frequency of interdisciplinary connections made by journals, we present two graphics inspired by the network analysis made with the support of Ucinet software. Figure 1 shows the connections between disciplines (the sample consists of the journals classified under Sociology-Demography, Economics-Management, Political Science, Anthropology, Psychology and Philosophy, some of them being also classified under other disciplines such as Education Sciences, Epistemology ...). The stroke enlarges according to the number of journals classified under two connected disciplines' ensembles. This also helps to identify the disciplines' ensembles most commonly associated by the journals. Figure 2 represents the connections between the journals (in blue) and the disciplines (in

Figure 1

\section{Disciplines Connections Network}

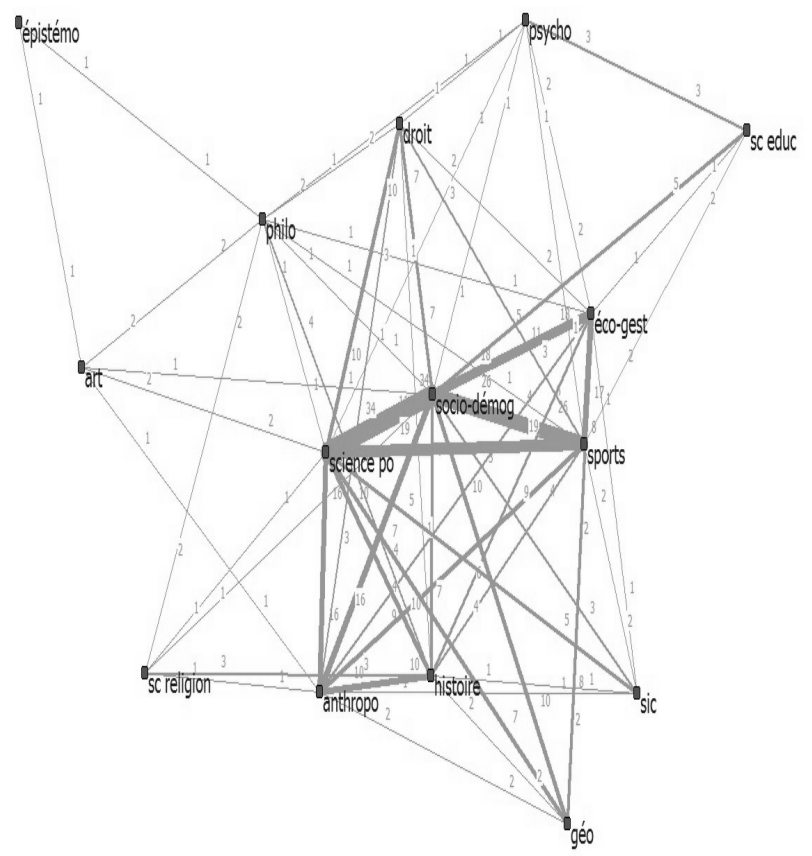


Figure 2

Journals and Disciplines Connections Network

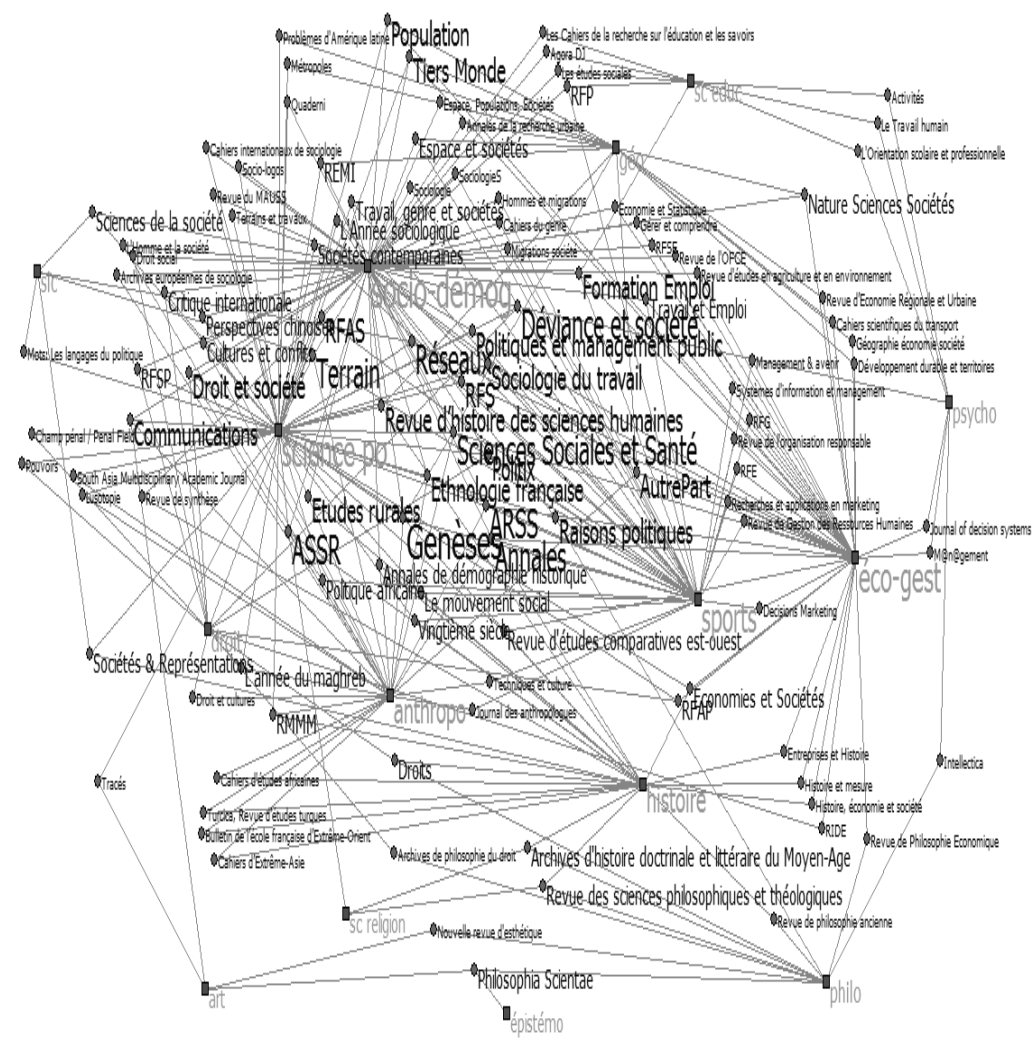

orange) under which they are classified. Only journals classified under at least two disciplines appear in this network. The font size increases, concerning the journals, according to the number of disciplines under which they are classified; and for the disciplines' ensembles, depending on the number of journals to which they are attached. This second graph helps specially to identify the journals that are recognized in a large number of disciplines' ensembles at the same time (located at the center of the graphic and in a larger font size).

As shown in Figure 1, the disciplinary couple which undoubtedly emerges most clearly from our sample of journals is that formed by Sociology and Political Science: 34 journals in our database are 
classified both as Sociology-Demography and as Political Science by AERES, which represents almost half of the 76 French journals classified under Sociology-Demography and 63\% of the 54 French journals classified under Political Science. We clearly see the result of the fact that, in France, Political Science became autonomous vis-à-vis Public Law and further progressed based on the principles of sociological research. Thus, most of the major French journals on Political Science, such as the Revue française de science politique, Politix, Critique international, Culture $\mathcal{E}$ Conflicts and Raisons politiques are situated under the Sociology-Demography list by AERES.

And, on the contrary, the main French Sociology journals are generally included under Political Science by AERES. This means that the French communities of sociologists and political scientists are now permeable, as shown by the procedures for qualification of lecturers' function by $\mathrm{CNU}$ sections for these two disciplines: they share indeed many regularly co-qualified.

The Sociology-Demography field also maintains numerous connections with Sciences et techniques des activités sportives (Staps): $34 \%$ of journals classified as Sociology-Demography are also in this field.

It is interesting to note two opposite practices by such thematic and interdisciplinary fields. The list of Staps integrates many major general journals in Sociology (as the Revue française de sociologie), Sociologie du travail, Actes de la recherche en sciences sociales but also in Anthropology, the Journal des anthropologues, Techniques et culture, in Political Science Politix, Raisons politiques, in History Annales, Vingtième siècle, Mouvement social or Management Decisions Marketing, Systèmes d'information et management. Everything happens as if Staps representatives at the origin of this list did not think of it so much as a separate discipline but as a multidisciplinary aggregate around a common theme (sports), so that they consider that publishing in the main generalist journals of different Social Sciences disciplines is a criterion for a positive evaluation by a researcher or a team in Staps.

On the contrary, those responsible for the list of journals of Education Sciences have opted for a Malthusian definition of their field, as shown by the weak linkages between this discipline and the others in Figure 1. This certainly reflects their inclination to strengthen Education Sciences as a separate discipline, even though this field of research is 
traditionally linked to other disciplines in France, specially Sociology and Psychology.

Some of the journals in the Education Sciences list confirm these historic links: Activités, Le Travail humain and L'Orientation scolaire et professionnelle are recognized both under Education Sciences and under Psychology, while La Revue française de pédagogie (founded in 1967, generally considered one of the main places for publishing educational research, if not the most important one), Les Cahiers de recherche sur l'éducation et les savoirs, Agora Débats/Jeunesse and Formation Emploi are both under Education Science and Sociology-Demography (but also under Economics-Management for Training-Employment).

Besides its links with Political Science and Staps, Sociology is also connected in a substantial manner with Economics-Management and Anthropology: around $20 \%$ of the journals classified as Sociology-Demography are also under the above mentioned areas. Sociology thus appears, from the point of view of the assessment bodies, a particularly open discipline vis-à-vis the other disciplines. The journals that can be considered the main general journals of Sociology (ie Actes de la recherche en sciences sociales, Revue française de sociologie, Sociologie du Travail, Sociétés contemporaines (Contemporary Societies)) are also systematically classified under at least three disciplines' ensembles of AERES: Sociology-Demography, Political Science and Staps. Even the journals that originate within the professional associations of the discipline (Socio-logos and SociologieS), created in 2006 by the French Association of Sociology and the International Association of French Speaking Sociologists, are also classified under other disciplines, namely Political Science for the first and Staps for the second. Among the 15 journals that are classified only under Sociology-Demography, excluded in any other disciplines' ensemble, on the contrary, we will find the journals that are often considered less important and/or which focus on a particular theme.

But if the inclination of Sociology journals to be classified also under other disciplinary fields may appear, at first glance, as an indicator of the attractiveness of this discipline in the Social Sciences in general (contradicting the cases of the main journals in the field of Anthropology-Ethnology, which struggle to be recognized under other disciplines), the general observation about the openness of 
Sociology reminds us of a diagnosis of "balkanization" often said about this discipline "open to all winds" (Amiot, 1984; Soulié, 2001). The apparent openness of Sociology is that it is likely to be interpreted as an illustration of its dominated position in relation to certain canonical disciplines, much older and which unification allows the establishment of Malthusian practices regarding the recruitment of personnel:

Unlike teaching disciplines [such as Philosophy or History], where the secondary education recruitment concourses play a key role in the reproduction of the faculty and in the internalization of a homogeneous habitus based on a "common sense" and alumni khâgnes ${ }^{10}$ - scholastic products particularly "pure" because of the academic and social closeness of classes - occupy the top of the academic hierarchy, on the contrary Sociology is characterized by the high dispersion of recruitment, limited control exercised by sociologists on their initial training and recruitment, openness to the secular world and its concerns' (Soulié and Mauger, 2001:8).

\section{THE INTERDISCIPLINARITY OF “CULTURAL AREAS"}

In the case of journals classified under the Anthropology-Ethnology field, we observe, in the first place, relatively common combinations with Sociology-Demography, here also consistent with the co-qualifications of CNU.

However, unlike what can be observed in the case of the pair Sociology-Political Science, Anthropology journals involved in these connections do not appear as the main journals of the discipline - with the exception of three journals that deal primarily with western societies, namely Ethnologie française, Terrain and Études rurales - but as journals in the Social Sciences in general (Annales HSS, Actes de la recherche en sciences sociales, Genèses, Archives de sciences sociales des religions...). Hence, the journal L'Homme founded in 1961 by Claude Lévi-Strauss and which can be considered the main French journal of Anthropology, is classified by AERES only under this discipline. The same occurs with the oldest journals in the discipline, such as Bulletins et Mémoires de la Société d'anthropologie de Paris, the Journal de la Société des américanistes, the Journal des africanistes and the Journal des océanistes founded respectively in 1859, 1895, 1931 and 1945. 
That means that the stress between Sociology and Anthropology, concerning the opposition between the study of "our" societies versus the study of "theirs", although regularly challenged by researchers representing the Ethnology current in France (Weber, 2012), helps to further differentiate the two disciplines today. The journals recognized by AERES related to Anthropology are, in fact, journals defined by a geographical area. On the contrary, only five journals from those classified as Sociology-Demography focus on a geographical area: Ethnologie française, Terrain ("Journal of Europe Ethnology"), Autre-Part ("Social Science Journal in the South"), Tiers-Monde and Perspectives chinoises. Of these five journals, only one of them, Tiers-Monde, is not classified furthermore under AnthropologyEthnology by AERES.

Another indicator may be brought up to highlight the frequent association between Anthropology and the study of non-Western societies. Indeed, we noticed that many journals delimited by geographical areas recognized by AERES under Anthropology, even though they do not seem to be "primarily" anthropological from the point of view of the composition of their editorial board, could include both geographers, historians, political scientists, linguists ... The same happens to Caravelle classified exclusively under Anthropology although it recognizes itself as being "resolutely interdisciplinary" and its editorial team includes mainly professors in Latin American literature, language and civilization studies. Similarly, the journal Cahiers des Amériques Latines which considers itself as "multidisciplinary" and situates itself in the field of Human and Social Sciences, whose editorial board is currently led by a political scientist and a geographer, is classified only under Anthropology by AERES. We could take other examples like La Revue d'études tibétaines or Archipel.

Anthropology, while being associated with several journals in Sociology (mainly by Ethnology journals of Europe or France), is also associated with Political Science, reflecting again what happens mostly by journals of cultural areas - like the Revue des mondes musulmans et de la Méditerranée, Politique africaine or Lusotopie - Political Science itself being heavily invested in this field of the study of cultural areas. Ten journals in our sample are also classified under Anthropology-Ethnology and History, which certainly represents a tiny minority among the many French journals classified under 
History (a canonical discipline whose faculty members formed by professors-researchers in universities is very high), but still, $16 \%$ of 54 French journals are classified under Anthropology-Ethnology. Again, if we put aside a group of highly interdisciplinary journals, which will be discussed below, these connections relate mainly to areas of cultural magazines: The Bulletin de l'école française d'Extrême-Orient, Les Cahiers d'extrême-Asie, La Revue des Mondes Musulmans et de la Méditerranée, Les Cahiers d'études africaines, Turcica.

In summary, while interdisciplinarity seems to have, in the case of Sociology, a central position in the Social Sciences (the sociological approach is important in Political Science as well as in educational research or in Information and Communication Sciences), it is relevant mainly in the case of Anthropology through collaborations originated by the study of given cultural areas (with sociologists in the case of French Ethnology and with political scientists, historians, geographers, and other specialists engaged in the study of other "civilizations").

\section{THE HISTORY BETWEEN “HUMANITIES" AND "SOCIAL SCIENCES"}

Let us remind ourselves that the only journals classified under History present in our sample are those classified elsewhere under one of the four following groups: Sociology-Demography, EconomicsManagement, Anthropology-Ethnology, Political Science (complemented, with regard to the information on AERES rankings, by Philosophy and Psychology).

One can nevertheless, through the tool "JournalBase" already mentioned, observe the disciplines commonly associated with History. It shows, firstly, that this discipline appears to be significantly less open than Sociology: the number of French journals classified both under History and under another area seems low when compared to the very large number of French journals classified in the field "History, Art History, Archeology".

Note that the second most common combinations involving History relate to Theology and Religions Sciences on the one hand and Philosophy on the other hand. One can note, in passing, the proximity of several disciplines akin to Humanities on the left side of Figure 1: the fields Arts, Epistemology, Theology and Religions Studies covering few journals in our sample, are indeed very much connected to History 
and Philosophy, the latter being itself connected mainly to History (four journals).

Nevertheless, History also maintains, through some often very prestigious journals, connections with Social Sciences such as Sociology and Political Science. In our compilation, among the most clearly multidisciplinary journals in the fields covered by SHS, and which occupy a central position in Figure 2, several of them are related primarily to History as a discipline: it is the case, in particular, of the journal Annales, histoire, sciences sociales founded in 1929 by Marc Bloch and Lucien Febvre and is now ranked by AERES under five disciplines' ensembles: History, Anthropology-Ethnology, Sociology-Demography, Education Sciences, EconomicsManagement.

Traditional representatives of the École des Annales are, in effect, among the most active promoters of the increase, in educational and research institutions in France, of an approach both unitary and critical of Economics and Social Sciences. In the late 1940s, Fernand Braudel and Lucien Febvre were therefore at the origin of the creation of the sixth section of the École Pratique des Hautes Études, which became the current École des hautes études en sciences sociales (EHESS), today a central training institution for research on History, Anthropology and Sociology. Furthermore, in 1962 Braudel was the first director of another central institution in promoting interdisciplinarity: la Maison des sciences de l'homme.

Similarly, Genesis, a journal founded in 1990 by researchers located at the crossroads of History and Political Science, and with the displayed goal of "contributing to the social History of the sciences closer to the history of society" is now classified under six disciplines at the same time: History, Anthropology-Ethnology, Sociology-Demography, Staps, Political Science and Geography.

Fall into this group of journals classified by AERES under various disciplines, Actes de la recherche en sciences sociales ("RHSO" in Figure 2) founded in 1975 by the sociologist Pierre Bourdieu (classified under Anthropology-Ethnology, Sociology-Demography, EconomicsManagement, Staps, Political Science) and several thematic journals as Archives de sciences sociales des religions ("ASSR", founded in 1956 under the original title of Archives de sociologie des religions, Déviances et 
sociétés (1977), Sciences sociales et santé (1982), or Réseaux (1983) and Terrains (1983).

\section{Economics at the periphery of SHS?}

Likewise the journals classified under History, those classified under Economics-Management are rarely also classified under other disciplines compared with those classified in Sociology-Demography and Political Science. Moreover, among the journals classified under Economics-Management and also under a cumulative ranking in many disciplines at once, few of them can be attached mainly to Economics. Tiers-Monde under Development Economics, an exception to the rule, is classified also under Sociology-Demography, Political Science and Geography. One must also mention the journal Économie et sociétés, founded by François Perroux under Libération, whose interest in other Social Sciences without any doubt contributed to classify it under Economics-Management, under Political Science and under History.

With this in mind, we observed relatively frequent combinations of AERES rankings in Economics and Sociology. If we put aside the group of the highly interdisciplinary journals already mentioned, these combinations are established, for a large part, by journals published by leading French agencies in charge of the study and the statistical diagnosis of economic and socio-demographic conditions, such as Population (Population), a journal of the Institut national des études démographiques (INED), Économie et statistique, published by the Institut national de la statistique et des études économiques (INSEE), Travail et Emploi, published by the Ministère du Travail (Ministry of Labor), La Revue de l'OFCE, the journal of the Observatoire français des conjonctures économiques, Formation Emploi the journal of the Centre d'étude et de recherches sur les qualifications (Centre of Studies and Research on Qualifications) (Céreq). We should also mention the case of Revue française de socio-économie, recently founded (in 2008) and which illustrates the current boom of Economics Sociology in France (Convert, 2001).

However, if Figure 1 reveals apparently significant links between Economics-Management and Political Science, in fact a closer look shows no Political Science journals strictly classified under Economics-Management, and vice versa. Similarly, the apparent links 
between Economics-Management and Staps do not really explain the classification of Economics journals under Spats (with the exception of the Revue française d'économie and Formation-Emploi: the group of journals combining these two areas includes mainly Sociology journals and / or highly interdisciplinary in one side and Management journals in the other.

Finally, Economics and Anthropology offer few combinations. Only four journals are classified under these two areas at the same time. Moreover, it is not about "Anthropology Journals" or "Economics Journals" but, again, very interdisciplinary journals such as Actes de la recherche en sciences sociales and the Annales. At this regard, it should be noted that several journals here seen as "recognized by AERES under Economics-Management" are actually kept away from this area by the creators of the list. Indeed, following a practice already observed with the list of journals carried out by the CNRS section of Economics-Management, we find that they have opted for the possibility of integrating "multidisciplinary" journals in their list and/or largely within other disciplines while distinguishing them from the journals of Economics and of Management by the refusal to grant them a ranking.

This means that apart from the historically maintained links with Sociology (in some statistical research organizations such as INSEE or Céreq or through the introduction in high schools, since the 1960s, of Social and Economic Sciences), few French journals of Economics turned to other disciplines in the field of SHS. What further confirms the co-qualifications by $\mathrm{CNU}$, which puts this discipline firstly in connection with management and then with Applied Mathematics. Thus, just as Psychology (highly connected with Neuroscience), Economics appears mainly as one of the few sections of the field "Law, Literature and Humanities" to turn to the sections of the field "Natural Sciences".

It is interesting to note here that among the journals classified by AERES in the field Economics-Management, many of them are not accessible on the web portals which French sociologists or historians typically use (Cairn, revues.org, persee). It concerns mainly Management journals, which number has increased in recent decades. Of the 82 French journals in our database classified by AERES in the field "Economics-Management", nearly a third relate primarily to 
Management Science (including Marketing, Human Resources Management, Strategy, Accounting, Public Management, Corporate Governance, etc.). Most of these journals were founded around the second half of the 1980s, corresponding to a period of dramatic increase in student enrollment and teachers-researchers on Management in French universities (today they exceed relatively numerous Economic Science students and academics).

It should be also noted that the French Economics journals are usually only "secondary" journals from the standpoint of French economists. This is confirmed by CNRS's Section 37 ranking (Economics-Management): journals of Economics and of Management classified under "category 1", that is to say, those which are considered by the members of the section as "particularly outstanding" in terms of published articles 'innovative' character, transparency and requirements for the process of selection of articles, selectivity and application of strict ethical rules are found to be mainly found among Anglo-Saxon journals. This suggests that Economic Science in France is only the subset of a larger field, international and dominated by American and English researchers (Lebaron, 2000). The apparent isolation of Economics-Management in the French Social Sciences can be interpreted rather as a privileged orientation towards other areas: Applied Mathematics and Anglo-Saxon Economics.

\section{CONCLUSION}

Connections established by Social Sciences journals with the field of "Natural Sciences" or "Life Sciences" appear to be substantially scarcer than the connections between Social Sciences disciplines themselves, without however losing sight of the particular cases of Psychology and Economics. Concerning the internal permeability of SHS, it should be said that it is important to remember that, even when journals often cultivate interdisciplinary collaboration through the establishment of their governing committees, the boundaries between disciplines continue to structure, to a large extent, the research activities and to differentiate the places available for scientific publishing. The very existence of lists of journals by discipline (or rather by disciplines' ensembles) developed by a national assessment agency, AERES, is one indicator among many.

While the major journals of Sociology and Political Science are almost all classified in other areas and are characterized by high permeability 
between them, this is not the case with regard to other disciplines considered here. L'Homme, a journal founded in 1961 by Claude Lévi-Strauss, which can be considered the main French journal of Anthropology, is classified only under this discipline. La Revue économique, Les Annales d'économie et de statistique, Économie \& Prévision, which are among the main French Economics journals appear under Economics-Management.

It would be wrong to see on the greater "openness" of some disciplines a unique criterion of their symbolic domination in the French academic field. If the journals classified under many disciplines are generally very prestigious journals in France, the openness of disciplines, which has certainly something to do with power relations between disciplines, primarily seems to reflect different strategies. Thus, the most apparent closure of Education Sciences, when compared to Staps, cannot be interpreted in terms of the degree of prestige between them, but as the opposition between the Malthusian strategy of a discipline which, though long established in French universities, seems to do everything to maintain at distance a derogatory image of a single aggregate almost "unnatural" of sociologists and psychologists of Education; and another area that is greatly situated at the margin in such way that it cannot exist as a field of research but that of a study topic summoning the theoretical and methodological contributions of different Social Sciences ${ }^{11}$. Similarly, the apparent "closure" of Economics, which must already be nuanced by the frequent orientation of the "heterodox" French economists vis-à-vis the other Social Sciences, reflects less the dominated position of Economics in the French academic world when compared to Sociology or Political Science, than the preferred orientation of French economists towards the Anglo-Saxon model and at the same time to its interest in Applied Mathematics.

Finally, we note that such combinations, as they are recognized by AERES, are not often associated with the long-institutionalized disciplines, such as History, Anthropology, Economics, Sociology (keeping however in mind the tradition of Socio-Economic studies and their results, which combines Economics and Sociology inside organizations like the INSEE, INED or Céreq, and which demonstrate, moreover, the existence in France of the education on Social and Economic Sciences in high schools). They rather combine these "mother" disciplines with more 'thematic' disciplines and/or with 
recently institutionalized disciplines. These combinations reflect well both the proximity with study objects, methods and issues, as well as the alliances established within the framework of the disciplines empowerment process whose very existence, as a totally separate discipline, is often a controversial issue. Sometimes they remind us of these ancient disciplines subordination and recently institutionalization (as in the case of Political Science which still maintains some links with Law where, in France, it originated). Clearly, these combinations indicate not so much the entrance of a new phase in the history of science marked by a hypothetical disappearance of disciplines, but moreover the history of divisions of study objects and areas of expertise between scientific disciplines, a history strongly rooted in national institutions and which the reader will have understood that it can foster misunderstandings at the level of international collaborations.

(Recebido para publicação 5 de agosto de 2015) (Aprovado para publicação 15 de abril de 2016) 


\section{NOTES}

1. These documents are to be found online at: http://www.enseignementsup-recherche.gouv.fr/cid98085/qualification-pr-et-mcf-archives.html

NT : Lecturers and Professors, respectively

2. See "disciplinary proximity" dated 24 January 2012 and "Bilan de la qualification CNU" dated 22 February 2014 in the blog of Baptiste Coulmont (Coulmont, 2012, 2014). See also Renisio and Zamith (2015).

3. This is the case, for instance, of a bibliometric survey by the SHS French journals by CNRS in 2004 (Henriot, Fleuret, 2004; Heilbron, Bokobza, 2015).

4. AERES has been established in 2007 as an independent administrative authority, in the line of the recommendations emanated from the "Processus de Bologne" created in 1998, and aiming at the harmonization of the European higher education systems. The AERES was particularly responsible for the evaluation of higher education and research institutions as well as French research organizations and units. In 2013, it was replaced by the Conseil de l'évaluation de la recherche et de l'enseignement supérieur (High Council for Research and High Education Evaluation) (HCERES), in charge of the same mission.

5. Under this article, the list used for Sociology-Demography is that of June 2013, the one for Anthropology is that of December 2012, the one for Economics-Management is the one for October 2012, the one for Political Science is dated October 2011, the one for Psychology is dated July 2011, and, last, the one for Philosophy is dated October 2013. These lists may be presented differently. Thus, the Economics-Management list provides a classification of journals ranking from " $\mathrm{A}$ " to " $\mathrm{C}$ ", a practice that is not taken in other lists. Indeed, the initial inclination of the AERES to achieve such a ranking based on the "radiation" journals met strong protests in France by faculty and magazines who saw the adverse developments of a shortsighted bibliometric evaluation, so they were abandoned ... except in the case of Economics-Management (which is, by the way, meaningful to the conceptions of scientific practice prevailing among economists in France).

6. This is based on the sample comprising the relevant journals in Sociology, Demography, Economics, Management, Political Science and Anthropology, Ethnology ( $\mathrm{N}=$ 198).

7. To identify the two "main" discipline journals within our sample, regardless of their rankings by AERES, we adopted as the main criterion the composition of the editorial board.

8. For a quick overview of the role of the $\mathrm{CNU}$, see note 1 above.

9. The "agrégation du supérieur" is a concourse that governs the access to the body of "Professors of Universities" (as opposed to the body of "Lecturers", see note 1 above) in the case of disciplines from former Law schools: this is the case of Political Science, Economics and Management Sciences.

10. NT: khâgne, cagne: a school slang meaning students preparing for l'École Normale Supérieure Lettres or École normale supérieure. Reverso Dictionary http://dictionary.reverso.net/french-definition/ $\mathrm{kh} \% \mathrm{C} 3 \% \mathrm{~A} 2 \mathrm{gnes}$. 
11. Staps are a section in French universities, but it only reflects the existence within them of an education devoted to the training of future teachers of physical education. In other words, Staps have no existence in the most prestigious places of the French academic field. We do not find the "pulpit" of Staps at the College of France, or a Staps section at CNRS, etc. 


\section{BIBLIOGRAPHIE}

AMIOT, Michet. (1984), “L'Enseignement de la Sociologie et la Recherche Universitaire”. Revue française de sociologie, vol. XXV, pp. 281-291.

CONVERT, Bernard. (2001), "Le Renouveau de la Sociologie Économique”. Journal des Anthropologues, no 84, pp. 87-110.

COUlMONT, Baptiste. (2012), “Proximités Disciplinaires”. Baptiste Coulmont Blog [online]. Disponible à: http://coulmont.com/blog/2012/01/

. (2014), "Bilan de la Qualification CNU". Baptiste Coulmont Blog [online]. Disponible à: http:/ / coulmont.com/blog/2014/02/22/la-qualif-2013/

GIBBONS, Michael et al. (1994), The New Production of Knowledge: The Dynamics of Science and Research in Contemporary Societies. London, Sage.

NOWOTNY, Helga; SCOTT, Peter; GIBBONS, Michael. (2001), Re-Thinking Science: Knowledge and the Public in an Age of Uncertainty. Cambridge, Polity Press.

HENRIOT, Christian; FLEURET, Étienne. (2004), "La Méthodologie". Lettre du Département des Sciences de l'Homme et de la Société du CNRS, no 69, pp. 53-54.

HEILBRON Johan; BOKOBZA, Anaïs. (2015), “Transgresser les Frontières en Sciences Humaines et Sociales en France". Actes de la Recherche en Sciences Sociales, no 210, pp. 108-121.

HEILBRON, Johan; GINGRAS, Yves. (2015), "La Résilience des Disciplines". Actes de la Recherche en Sciences Sociales, no 210, pp. 4-9.

LAMY, Jérôme. (2007), “Penser les Rapports entre Sciences et Politique: Enjeux Historiographiques Récents". Cahiers d'Histoire. Revue d'Histoire Critique, no 102, pp. 9-32.

LEBARON, Frédéric. (2000), La Croyance Économique. Les Économistes entre Science et Politique. Paris, Seuil.

RENISIO, Yann; ZAMITH, Pablo. (2015), “Proximités Épistémologiques et Stratégies Professionnelles. Qualifier l'interdisciplinarité au CNU, 2005-2013". Actes de la Recherche en Sciences Sociales, no 210, pp. 28-39.

SHINN, Terry. (2002), “Nouvelles Productions du Savoir et Triple Hélice. Tendance du prêt-à-penser les Sciences". Actes de la Recherche en Sciences Sociales, nos 141-142, pp. 21-30.

SOULIÉ, Charles; MAUGER, Gérard. (2001), “Le Recrutement des Étudiants en Lettres et Sciences Humaines et leurs Objets de Recherche". Regards Sociologiques, no 22, pp. 23-40.

WEBER, Florence. (2012), “De l'Ethnologie de la France à l'Ethnographie Réflexive". Genèses, no 89, pp. 44-60. 


\section{RESUMO}

\section{A Interdisciplinaridade nas Revistas Científicas Francesas de Ciências} Sociais.

Tratando do caso francês, esse artigo examina as relações entre disciplinas das Ciências Sociais descobertas durante a árdua tarefa de classificar as revistas francesas de Ciências Sociais segundo disciplinas mais específicas (sociologia, ciência política, antropologia...). A partir do estudo das práticas de autorrotulação das próprias revistas, das práticas de classificação dessas revistas por um organismo francês de avaliação (AERES) e igualmente da composição de comitês executivos de revistas, esse artigo destaca o fato de as revistas abrangerem frequentemente várias disciplinas, sem que isso implique um desaparecimento das estruturas disciplinares. De fato, o artigo demonstra que as conexões realizadas pelas revistas entre diferentes disciplinas das Ciências Sociais são desigualmente prováveis e permitidas.

Palavras-chaves: Ciências Sociais; França; revistas científicas; AERES; interdisciplinaridade

\section{ABSTRACT \\ Interdisciplinarity in the Context of Scientific Journals}

Taking France as its example, the following article examines the relations between the disciplines of social sciences discovered during the arduous task of classifying French social sciences journals according to more specific disciplines (sociology, political science and anthropology, etc.). Based on a study of the journals' own methods of self-labeling and the methods used to classify these journals by a French assessment body (AERES), as well as the forming of journal executive committees, the article highlights the fact that the journals frequently cover a range of disciplines, without this implying the disappearance of disciplinary structures. In fact, the article instead reveals that the connections made by the journals between the various disciplines of social sciences are unlikely and disproportionately represented.

Keywords: Social Sciences; France; scientific journals; AERES; interdisciplinarity 


\section{RÉSUMÉ}

L'Interdisciplinarité à l'aune des Revues Scientifiques Françaises en Sciences Sociales

Portant sur le cas français, cet article examine les relations entre disciplines de sciences sociales telles qu'elles ressortent des difficultés rencontrées devant la tâche de classer les revues françaises de sciences sociales en disciplines "fines" (sociologie, science politique, anthropologie...). À partir de l'étude des pratiques d'auto-labellisation par les revues elles-mêmes, des pratiques de classement des revues par une instance française d'évaluation (AERES), mais aussi de la composition des comités directeurs des revues, cet article souligne que les revues recouvrent fréquemment plusieurs disciplines à la fois sans pour autant qu'on puisse y voir une disparition des structures disciplinaires. En effet, il montre que les connexions réalisées par les revues entre différentes disciplines des sciences sociales sont inégalement probables et permises.

Mots-clés: Sciences sociales; France; revues scientifiques; AERES; interdisciplinarité

\section{RESUMEN}

La Interdisciplinariedad en las Revistas Científicas Francesas de Ciencias Sociales

Al tratar del caso francés, este artículo examina las relaciones entre las disciplinas de las ciencias sociales encontradas durante la ardua labor de clasificar las revistas francesas de ciencias sociales según las disciplinas más específicas (sociología, ciencia política, antropología...). A partir del estudio de las prácticas de auto-etiquetado de las revistas, las prácticas de clasificación de dichas revistas por un organismo francés de evaluación (AERES) y la composición de los comités ejecutivos de las revistas, este artículo resalta el hecho de que las revistas a menudo abarcan varias disciplinas, sin que ello resulte en desaparición de las estructuras disciplinarias. De hecho, el artículo demuestra que las conexiones hechas por las revistas entre diferentes disciplinas de las ciencias sociales son desigualmente probables y permitidas.

Palabras clave: Ciencias Sociales; Francia; revistas científicas; AERES; interdisciplinariedad 